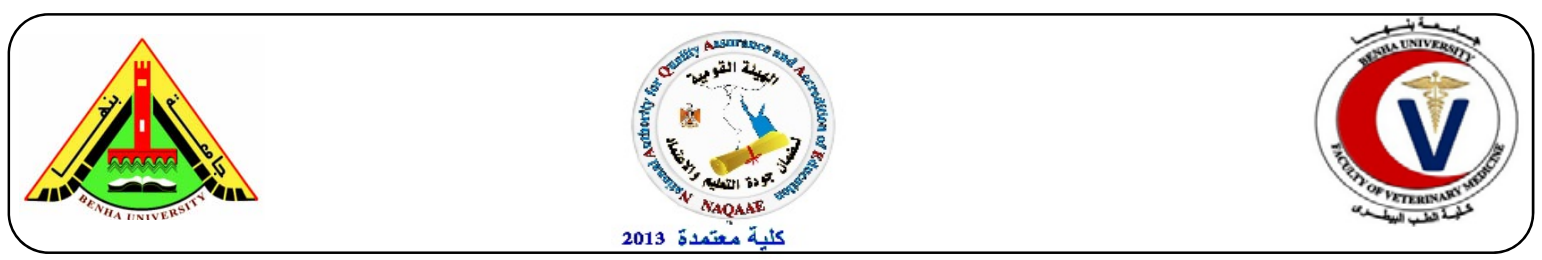

\title{
Biochemical changes in carbohydrates metabolism in experimentally induced rheumatoid arthritis in rats.
}

\author{
${ }^{1}$ Omnia M. Abd Elhamid, ${ }^{2}$ Khaled Mohamed Fararh, ${ }^{3}$ Mona Nawar Abdel Ghany \\ ${ }^{1}$ Biochemistry Department, Faculty of Vet. Med. Benha University, Egypt. ${ }^{2}$ Clinical Pathology \\ Department, Faculty of Vet. Med., Benha University, Egypt. ${ }^{3}$ Biochemistry Department, Faculty of \\ science, Al-Azhar University, Egypt.
}

\begin{abstract}
A B S T R A C T
In the present study, the effect of Complete Freund's adjuvant - induced rheumatoid arthritis on serum Glucose, Nitric Oxide, Cortisol, Lactic acid, Pyruvic acid, Pantothenic acid, Pentosidine, Na/K ATPase, Interleukin 8 and Sialic acid in rats have been evaluated. Forty female albino rats were divided into two equal groups (20 each). Group I (Control group): received no drugs. Group II: (Rheumatoid Arthritis group) injected subcutaneously with Complete Freund's adjuvant at a dose of $(0.1 \mathrm{mg} / \mathrm{kg}$ body weight dissolved in $1 \mathrm{ml}$ saline) for rheumatoid arthritis induction. Blood samples were collected from all groups after 2 and 4 weeks from injection. The obtained results showed that there is the experimental arthritis accompanied with significant increases in serum Glucose, Nitric oxide, Cortisol, Lactic acid, Pentosidine, Interleukin 8 and Sialic acid levels. On the other hands, pyruvic acid level, $\mathrm{Na} / \mathrm{k}$ ATPase activity and pantothenic acid levels were significantly decreased.
\end{abstract}

Key words: rheumatoid arthritis, pentosidine, pantothenic acid

(http://www.bvmj.bu.edu.eg)

(BVMJ-29(2): 92-99, 2015)

\section{INTRODUCTION}

$\mathrm{R}$ heumatoid arthritis (RA) is a chronic inflammatory autoimmune disease. Degradation of cartilage is a more complex event involving the local release of metalloproteases and lysosomal enzymes that mediate inflammation in joints and in the synovial fluid in RA (Mythilypriya et al, 2008). It is a chronic destructive disease of joints, characterized by inflammation, synovial hyperplasia, and abnormal cellular and humoral immune responses (Lee et al., 2002). It is considered as a disease with autoimmune etiology, though the network of factors determining and modifying its development and progression are incompletely understood . This type of chronic inflammation apparently results from a multitude of different pathways, and this situation necessarily reflects a poor efficacy of current therapeutic modalities (Kiely, 1998). Adjuvant arthritis (AA), induced in the Lewis rat by immunization with Mycobacterium tuberculosis, is an excellent model for rheumatoid arthritis. Clinically and pathologically the model is similar to human RA. It is an immunological model for progressive joint swelling, destruction and bone erosion. It has been shown to share certain clinical and immunological features with human arthritis (Kim and Moudgil.2009). The model is widely used, with a relatively high degree of validity, for testing drugs of anti-inflammatory and anti -rheumatic properties (Borah et al., 1995). Complete Freund's adjuvant, in general has been utilized to induce an arthritic immunepathological disease that displays many of the pathological features of human RA. Unilateral injection of Freund's adjuvant 
into the paw induces 'primary inflammatory signs and hyperalgesia within hours at the site of inoculation. Subsequently, secondary inflammatory and pronociceptive signs appear between the 10th and 15th day post-inoculation, especially in the contralateral paw. The hyperalgesia associated with injection of Freund's adjuvant may persist for 8 weeks after adjuvant injection (Philippe et al., 1997), Inflammation is a complex process involving numerous mediators of cellular and plasma origin with elaborate and interrelated biological effects. Nitric oxide (NO) and prostaglandin $\mathrm{E}_{2}\left(\mathrm{PGE}_{2}\right)$ which are involved in various pathophysiological processes including inflammation and carcinogenesis. Noticeably inducible nitric oxide synthase (iNOS) and inducible cyclooxygenase-2 (COX-2) are mainly responsible for the production of large amounts of these mediators (Jang et al., 2004). Increased serum levels of the NO breakdown products nitrate and/or nitrite have been found in patients with RA (Farrell et al., 1992). So the aim of this study to evaluate the effect of Freund's adjuvant injection in rats as experimental model

\section{MATERLAIS AND METHOD}

\subsection{Experimental animals:}

Forty white female albino rats of 12-16 weeks old and weighing 180-220 gm were used in the experimental investigation of this study. The rats were obtained from the Laboratory Animals Research Center, Faculty of Veterinary Medicine, Benha University. Rats were housed in separated wire mesh cages and kept at constant environmental and nutritional conditions throughout the period of the experiment. The animals were fed on constant ratio and fresh, clean drinking water was supplied ad -libitum. The animals were left 14 days for acclimatization before the beginning of the experiment.

\subsection{Drugs and Chemicals:}

Complete Freund's adjuvant is prepared in the form of solution (obtained from Sigma chemical company). The solution was injected subcutaneously at a dose of 0,1 $\mathrm{mg} / \mathrm{kg} \mathrm{b.wt}$ in the planter surface of the left hind paw for induction of rheumatoid arthritis (Mythilypriya et al, 2008).

\subsection{Experimental design:}

Rats were randomly divided into two equal groups, (20 rats each), placed in individual cages and classified as follows: Group I: normal Control group: received no drugs. Group II: Rheumatoid arthritis group: rats were injected by complete Freund's adjuvant at a dose of $(0,1 \mathrm{mg} / \mathrm{kg}$ b.wt, once $)$ in the planter surface of the left hind paw.

\subsection{Sampling:}

Blood samples were collected after overnight fasting from all animal groups twice after $15 \& 30$ days from induction of rheumatoid arthritis

Blood samples were collected by ocular vein puncture on clean and screw capped tubes. Serum were separated by centrifugation at 2500 r.p.m for 15 mins. The clean, clear serum was separated by automatic pipette and received in dry sterile samples tube and kept in deep freeze at$20^{\circ} \mathrm{C}$ until used for subsequent biochemical analysis. All sera were analyzed for glucose, nitric oxide, cortisol, lactic acid, pyruvic acid, pantothenic acid, pentosidine, $\mathrm{Na} / \mathrm{K}$ ATPase, interleukin 8, sialic acid determination.

\subsection{Biochemical analysis:}

Serum was used for estimation of glucose according to Trinder (1969), nitric oxide according to Montgomery and Dymock (1961), cortisol according to according to Rat Cortisol Elisa kit (Catalog No: E0462r), lactic acid according to Noll, (1988), pyruvic acid according to Sutherland et al., (1994), sodium potassium ATPase according to (Pressley etal,1986), pantothenic acid using the method of (Coronel et al, 1991), pentosidine according to Mouse Pentosidine Elisa kit (Catalog Number: MBS720401). 
interleukin 8 according to Rat Interleukin- 8 (IL-8) Elisa kit (Cat. No. MBS723870), sialic acid according to Human Sialic acid (SA) Elisa kit (Cat.No.CSB-E09605h).

\subsection{Statistical analysis:}

The Statistical analysis was carried out using $\mathrm{T}$ test with two factors under significance level of $0.05,0.01,0.001$ for the whole results using SPSS (ver. 19). Data were treated as complete randomization design according to Steel et al. (1997). (SPSS, 13.0 software). Values at 0.05 were considered to be significant.

\section{RESULTS}

The obtained results in table $(1 \& 2)$ revealed that, Complete Freund's adjuvant injection to normal rats exhibited a significant increase in serum glucose, nitric oxide, cortisol, lactic acid, pentosidine, interleukin 8, sialic acid levels. On the other hands, significant decrease was found in pyruvic acid level, $\mathrm{Na} / \mathrm{k}$ ATPase activity, pantothenic acid level when compared to control normal group.

\section{DISCUSSION}

The obtained results showed significant increase in serum glucose level and this may due to serum glucose - 6- phosphate isomerase (GPI) level correlated positively with the synovitis of RA. Significantly higher soluble GPI levels were detected in the RA sera compared with sera from the non-RA disease controls and the healthy controls. The rate of serum GPI positivity was significantly higher in the RA patients than in the non-RA disease controls. Thus, elevated serum glucose-6-phosphate isomerase GPI may be involved in the synovitis of RA and may prove useful as a serum marker for disease activity of RA (Dai et al., 2010).

To assess NO production in RA patients, we compared levels of serum NO in RA induced and normal rats. Our results revealed that serum from $\mathrm{RA}$ induced rats have highly significant elevated NO levels when compared with the control group. NO production appropriate levels are important to protecting many organs from ischemic damage, whereas chronic expression of NO is associated with various malignancies and inflammatory conditions including multiple sclerosis, arthritis, juvenile diabetes, and ulcerative colitis (Al-nimer et al., 2010).

An inappropriate low secretion of cortisol is a typical feature of the inflammatory disease in patients with rheumatoid arthritis (Ahmed et al., 2005). However, cortisol levels in RA patients are described as low (Hedman et al., 1992), normal (Dougados et al., 1983) or elevated (Spector et al., 1987). This controversy may be explained in the light of the suggestion that cortisol levels depend on the melatonin levels. As, in rheumatoid arthritis, high melatonin levels is associated with low cortisol levels and this could depend on a variety of factors. One of these might be an abnormal response to bright light in patients with rheumatoid arthritis. It has been shown that the transition from dim light to bright light in the morning results in an immediate surge of cortisol in healthy individuals. That is because of the reduction in melatonin inhibition (higher melatonin values) at the end of the hours of darkness (Cutolo et al., 2005). Angiogenesis, the formation of new blood vessels emerging from preexisting endothelial vasculature, plays a crucial role in a wide range of physiological events including embryonic development, placental implantation, and wound healing for the delivery of oxygen and nutrients as well as removal of waste products. This process is also initiated in response to certain pathological conditions, such as solid tumor growth, diabetic retinopathy, psoriasis, and rheumatoid arthritis in which angiogenesis is responsible for the progression of such diseases. 
Table (1) The effects of complete Freund's adjuvant on serum glucose, nitric oxide, cortisol, lactic acid, pyruvic acid, pantothenic acid, pentosidine, $\mathrm{Na} / \mathrm{k}$ ATPase, interleukin 8 , sialic acid, on experimentally rheumatoid arthritis in rats after 2 weeks.

\begin{tabular}{|c|c|c|c|c|c|c|c|c|c|c|}
\hline $\begin{array}{l}\text { Animal } \\
\text { groups } \\
\text { parameter }\end{array}$ & $\begin{array}{l}\text { glucose } \\
\mathrm{mg} / \mathrm{ml}\end{array}$ & $\begin{array}{c}\mathrm{NO} \\
\mathrm{Mmol} / 1\end{array}$ & $\begin{array}{c}\text { Cortisol } \\
\mathrm{ng} / \mathrm{ml}\end{array}$ & $\begin{array}{c}\text { Lactic acid } \\
\mathrm{Mmol} / 1\end{array}$ & $\begin{array}{c}\text { Pyruvic } \\
\text { acid } \\
\text { Mm/well }\end{array}$ & $\begin{array}{c}\mathrm{Na} / \mathrm{K} \\
\text { ATPase } \\
\text { nmol }\end{array}$ & $\begin{array}{c}\text { Pntotheni } \\
\mathrm{c} \text { acid } \\
\mathrm{Mg} / \mathrm{l}\end{array}$ & $\begin{array}{l}\text { pentosidine } \\
\mathrm{PMol} / \mathrm{ml}\end{array}$ & $\begin{array}{c}\text { IL-8 } \\
\text { ng.L-1 }\end{array}$ & $\begin{array}{l}\text { Sialic acid } \\
\mathrm{mg} / \mathrm{dl}\end{array}$ \\
\hline Control & $35.84 \pm 2.05$ & $35.84 \pm 2.05$ & $8.44 \pm 0.89$ & $7.18 \pm 0.48$ & $24.88 \pm 1.28$ & $355.20 \pm 14.29$ & $2.34 \pm 0.21$ & $49.67 \pm 2.05$ & $63.81 \pm 6.19$ & $46.32 \pm 2.30$ \\
\hline $\begin{array}{l}\text { Rheumatoi } \\
\text { d arthritic }\end{array}$ & $\underset{* *}{59.48 \pm 1.57}$ & $59.48 \pm 1.57$ & $\begin{array}{c}11.06 \pm 0.8 \\
4\end{array}$ & $\begin{array}{c}10.23 \pm 0.29 \\
*\end{array}$ & $\begin{array}{c}19.32 \pm 1.25 \\
*\end{array}$ & $\begin{array}{c}258.09 \pm 9.56^{*} \\
*\end{array}$ & $\begin{array}{c}1.37 \pm 0.23 \\
*\end{array}$ & $\begin{array}{c}92.38 \pm 9.96 \\
*\end{array}$ & $\begin{array}{c}133.27 \pm 3.54 * \\
*\end{array}$ & $\begin{array}{c}34.67 \pm 2.96 \\
*\end{array}$ \\
\hline
\end{tabular}

$($ mean \pm SE). SE: Standard error of mean*.

*Significant $(P>0.05), * *$ High significant $(P>0.01), * * *$ Very high significant $(P>0.001)$.

Table (2) The effects of complete Freund`s adjuvant on serum glucose, nitric oxide, cortisol, lactic acid, pyruvic acid, pantothenic acid, pentosidinee, $\mathrm{Na} / \mathrm{k}$ ATPase, interleukin 8 , sialic acid, on experimentally rheumatoid arthritis in rats after 4 weeks.

\begin{tabular}{|c|c|c|c|c|c|c|c|c|c|c|}
\hline $\begin{array}{l}\text { Animal } \\
\text { groups } \\
\text { parameter }\end{array}$ & $\begin{array}{l}\text { glucose } \\
\mathrm{mg} / \mathrm{ml}\end{array}$ & $\begin{array}{c}\mathrm{NO} \\
\mathrm{Mmol} / 1\end{array}$ & $\begin{array}{c}\text { Cortisol } \\
\mathrm{ng} / \mathrm{ml}\end{array}$ & $\begin{array}{c}\text { Lactic acid } \\
\mathrm{Mmol} / 1\end{array}$ & $\begin{array}{l}\text { Pyruvic } \\
\text { acid } \\
\text { Mm/well }\end{array}$ & $\begin{array}{c}\mathrm{Na} / \mathrm{K} \\
\text { ATPase } \\
\text { nmol }\end{array}$ & $\begin{array}{c}\text { Pntothen } \\
\text { ic acid } \\
\mathrm{Mg} / 1\end{array}$ & $\begin{array}{c}\text { pentosidine } \\
\mathrm{PMol} / \mathrm{ml}\end{array}$ & $\begin{array}{c}\text { IL-8 } \\
\text { ng.L-1 }\end{array}$ & $\begin{array}{l}\text { Sialic acid } \\
\mathrm{mg} / \mathrm{dl}\end{array}$ \\
\hline Control & $33.91 \pm 3.21$ & $33.91 \pm 3.21$ & $7.70 \pm 1.20$ & $8.00 \pm 0.55$ & $27.63 \pm 1.65$ & $\begin{array}{c}258.09 \pm 9.56^{*} \\
*\end{array}$ & $\begin{array}{c}2.58 \pm 0.2 \\
5\end{array}$ & $48.23 \pm 4.07$ & $64.85 \pm 6.20$ & $29.48 \pm 1.93$ \\
\hline $\begin{array}{l}\text { Rheumato } \\
\text { id arthritic }\end{array}$ & $\begin{array}{c}68.87 \pm 2.23 \\
* *\end{array}$ & $\begin{array}{c}68.87 \pm 2.23 \\
* *\end{array}$ & $\begin{array}{c}13.29 \pm 0.5 \\
6^{*}\end{array}$ & $\begin{array}{c}24.82 \pm 0.28 \\
* *\end{array}$ & $\begin{array}{c}11.58 \pm 0.79 \\
* *\end{array}$ & $\begin{array}{c}268.52 \pm 11.45 \\
* *\end{array}$ & $\begin{array}{c}1.10 \pm 0.6 \\
9^{*}\end{array}$ & $\begin{array}{c}88.25 \pm 3.76 \\
* *\end{array}$ & $\begin{array}{c}146.29 \pm 11.98 \\
* *\end{array}$ & $\begin{array}{c}51.77 \pm 1.20 \\
* *\end{array}$ \\
\hline
\end{tabular}


Also, the excessive progression of these diseases requires high glucose uptake rates and glycolysis and continuous recruitment of new blood vessels. In 2001, Lee et al. provide several lines of evidence showing that pyruvic acid, the end product of glycolysis, exhibits strong angiogenic activity. Pyruvic acid positively affects angiogenic cascade, DNA synthesis, migration, and tube formation in bovine aortic endothelial cells. Furthermore, mRNA expression of fibroblast growth factor receptor-2 and vascular endothelial growth factor was enhanced by pyruvic acid. These results strongly suggest that pyruvic acid plays an important role in angiogenesis (Lee et al., 2001). Raised serum lactic dehydrogenase levels were linked with progressive joint damage in patients with RA were reported the synovial fluid from patients with RA showed the polymorph LDH isoenzyme pattern by (Dawes et al., 1986).

In this study, we investigated the serum $\mathrm{Na}^{+} / \mathrm{K}^{+}$-ATPase levels in both $\mathrm{RA}$ and control groups. We found that the activity of $\mathrm{Na}^{+} / \mathrm{K}^{+}$-ATPase was significantly decreased in RA case. Erythrocyte membrane $\mathrm{Na}^{+} / \mathrm{K}^{+}$-ATPase activity negatively correlated with inflammation markers (Erythrocyte sedimentation rate (ESR) and C-reactive protein (CRP). The action of serum soluble E-selectin, is a cell adhesion molecule expressed only on endothelial cells activated by cytokines, on erythrocyte membrane $\mathrm{Na}+/ \mathrm{K}+$-ATPase activity may be mediated by a modification of the physicochemical properties of the membrane, such as fluidity or by an alteration in the protein environment of the enzyme. Also, decreased erythrocyte membrane $\mathrm{Na}+/ \mathrm{K}+$-ATPase activity in RA may be due to altered membrane function, including adhesive properties (Testa Yildirim et al., 2005). (GPRG, 1980) found that people with RA may have lower levels of B5 in their blood than healthy people, and the lowest levels were associated with the most severe symptoms. Other studies show that calcium pantothenate improves symptoms of RA, including morning stiffness and pain. More studies are needed to confirm these findings. Rheumatoid arthritis is a state of increased oxidative stress associated with chronic inflammation. This suggested an enhanced glycoxidation reaction and increased AGE levels in RA patients (Miyata et al., 1998). Our results were in agreement with this hypothesis. It was demonstrated that pentosidine levels were elevated in cartilage in RA and suggested that oxidative stress was related to the elevation of pentosidine in the cartilage of RA and Miyata et al., 1998). Similar results, increased concentrations of serum pentosidine in rheumatoid arthritis, were reported (by Miyata et al., 1998). In this study, there was a significant increase in serum IL-8 in RA, the synovial lining fibroblasts [also called fibroblast-like synoviocytes (FLS)] contribute in local production of cytokines, small molecule mediators of inflammation, and proteolytic enzymes that degrade the extracellular matrix. These RA fibroblastlike synoviocytes produce IL-6 and IL-8, which contribute to inflammation and joint damage (Georganas et al., 2000). IL-8 is a product at the end of the cytokine cascade, but it is the specific cytokine that upregulates neutrophil $\beta_{2}$ integrins and induces. neutrophil transmigration to inflammatory sites via a chemotactic gradient (Troughton et al., 1996). Serum sialic acid is known as a parameter of inflammation. serum SA levels were measured in patients with primary osteoarthritis (POA), inactive rheumatoid arthritis and healthy subjects. SA levels were determined spectrophotometrically in serum or plasma samples. SA serum levels were significantly increased in POA and RA, compared with healthy controls. Also, plasma total antioxidant activity, plasma superoxide dismutase activity and serum reduced glutathione levels were significantly decreased in patients with POA and those with RA. So, increased SA and protein oxidation levels are associated with the decreased antioxidant levels in 
POA and RA patients. Thus, these findings suggest that SA may be considered as a potent defense molecule against oxidative damage in arthritis (Alturfan et al., 2007).

\section{Conclusion and recommendation}

From the obtained results, it could be concluded that, complete Freund's adjuvant induced rheumatoid arthritis in female rats resulted in significant increase in serum glucose, nitric oxide, cortisol, lactic acid, pentosidine, interleukin 8 , sialic acid levels with significant decrease in pyruvic acid level, $\mathrm{Na} / \mathrm{k}$ ATPase activity, pantothenic acid level when compared to control normal group. We can recommend the detection of these markers each as individual or in a combination with other markers to provides useful information for diagnosis of RA.

\section{REFERENCES}

Ahmed, M.I., Afifi, M.I., Younos, I.H. 2005. Harpagophytumprocumbens (Devil's Claw): A Possible Natural Anti-Inflammatory Agent (An Experimental Study). Iranian Journal of Pharmacology \& Therapeutics; 4: 54-63.

Al-nimer, M.S.M., Al-obaidi, S.A., Aldulaimi, K.S. 2010. Serum nitric oxide and peroxynitrite levels in adultsero-positive rheumatoid arthritis treated with disease modifying antirheumatic drugs: a preliminary report. Turk J Med Sci; 40:191-197.

Alturfan, A.A., Uslu, E., Alturfan, E.E., Hatemi, G., Fresko, I., Kokoglu, E. 2007. Increased serum sialic acid levels in primary osteoarthritis and inactive rheumatoid arthritis. Tohoku. J. Exp Med; 213:241-248.

Barton-wright, E.C., Elliott, W.A. 1963. The pantothenic acid metabolism of rheumatoid arthritis. Lancet; 2:862863.

Borah, B., Frances, M.D., Havancik, K., Royce, J.T., Szeverenyi, N.M. 1995.
A quantitative one-dimensional magnetic resonance imaging technique in adjuvant arthritis; the assessment of disease. J Rheumatol; 22(5):855-862.

Chen, J.R., Takahashi, M., Suzuki, M., Kushida, K., Miyamoto, S., Inoue, T. 1998. Pentosidine in synovial fluid in osteoarthritis and rheumatoid arthritis: relationship with disease activity in rheumatoid arthritis. J Rheumatology, 25:2440-2444.

Coronel, F. 1991. Treatment of hyperlipemia in diabetic patients on dialysis with aphysiological substance. Am. J Nephroll1 1(1): 32-6.

Cutolo, M., Maestroni, G.J., Otsa, K., Aakre, O., Villaggio, B., Capellino, S, Montagna, P., Fazzuoli, L., Veldi, T., Peets, T., Hertens, E., Sulli, A. 2005. Circadian melatonin and cortisol levels in rheumatoid arthritis patients in winter time: a north and south Europe comparison. Ann Rheum Dis; 64:212-216.

Dai, L., Zhu, L.J., Zheng, D.H., Mo, Y.Q., Wei, X.N., Su, J.H., Pessler, F. Zhang, B.Y. 2010. Elevated serum glucose-6-phosphate isomerase correlates with histological disease activity and clinical improvement after initiation of therapy in patients with rheumatoid arthritis. J. Rheumatol; 37:2452-2461.

Dawes, P.T., Fowler, P.D., Jackson, R., Collins, M., Shadforth, M.F., Stone, R., Scott, D.L. 1986. Prediction of progressive joint damage in patients with rheumatoid arthritis receiving gold or D-penicillamine therapy. Ann Rheum Dis; 45: 945-949.

Dougados, M., Nahoul, K., Benhamu, L., Amor, B. 1983. Androgen plasma levels in female rheumatoid arthritis patients (Letter). Arthritis Rheum; 26: 935-936.

Farrell, A.J., Blake, D.R., Palmer, R.M., Moncada, S. 1992. Increased concentrations of nitrite in synovial fluid and serum samples suggested 
increased nitric oxide synthesis in rheumatic diseases. Ann Rheum Dis; 51: 1219-1222.

Georganas, C., Liu, H., Perlman, H., Hoffmann, A., Thimmapaya, B., Pope, R.M. 2000. Regulation of IL-6 and IL-8 Expression in Rheumatoid Arthritis Synovial Fibroblasts: The Dominant Role for NF- $\kappa$ B But Not C/EBP $\beta$ or c-Jun. J Immunol; 165: 7199-7206.

GPRG. General Practitioner Research Group. 1980. Calcium pantothenate in Arthritic Conditions. Practitioner; 224:208-211.

Hedman, M., Nilsson, E., de la Torre, B. 1992. Low blood and synovial fluid levels of sulpho-conjugated steroids in rheumatoid arthritis. Clin. Exp. Rheumatol, 10:25-30.

Jang, M.H., Shin, M.C., Kirn, Y., Kirn, J., Kirn, Y., Kirn, E.H. 2004. Atractylodes japonica suppresses Lipopolysaccharide-stimulated expressions of inducible nitrio oxide synthase and cyclooxygenase-2 in RAW 264-267. Macrophages. Biol. Pharm. Bull; 27 (3): 324-327.

Kim, E., Yand, k., Moudgil, D. 2009.The determinants of susceptibility/resistance to adjuvant arthritis in rats. Arthritis. Res.Ther. 11(4): 239.

Kiely, P.D.W. 1998. Th1-Th2 model_what revealance to inflammatory arthritis? Ann Rheum 57:328 330.

Kiziltunç, A., Coğalgil, S., Uğur, M., Avci, B., Akçay, F. 1998. Sialic acid, transketolase and $\mathrm{Na}^{+}, \mathrm{K}+$, ATPase in patients with rheumatoid arthritis. Clin Chem Lab Med; 36: 289-293.

Lee, D.M., Friend, D.S., Gurish, M.F., Benoist, C., Mathis, D., Brenner, M. B., 2002. Mast cells: a cellular link between autoantibodies and inflammatory arthritis. Science (Wash DC) 297: 1689-1692

Lee, M.S., Moon, E.J., Lee, S.W., Kim, M.S., Kim, K.W., Kim, Y.J. 2001. Angiogenic activity of pyruvic acid in in vivo and in vitro angiogenesis models. Cancer. Res; 61: 3290-3293.

Mirone, L., Altomonte, L., D'Agostino, P., Zoli, A., Barini, A., Magaro, M. 1996. A study of serum androgen and cortisol levels in female patients with rheumatoid arthritis. Correlation with disease activity. Clin. Rheumatol; 15:15-19.

Miyata, T., Ishiguro, N., Yasuda, Y., Ito, T., Nangaku, M., Iwata, H., Kurokawa, K. 1998. Increased pentosidine, an advanced glycation end product, in plasma and synovial fluid from patients with rheumatoid arthritis and its relation with inflammatory markers. Biochem Biophys Res. Commun; 244: 45-49.

Montgomery, H.A.C., Dymock, J.F. 1961. Colorimetric determination of nitric oxide. Analyst.86: 414-417.

Mythilypriya, R., Shanthi, P., Sachdananda, M.P. 2008. Efficacy of Siddha formulation Kalpaamruthaa in ameliorating joint destruction in rheumatoid arthritis in rats. Chemico biological Interactions; 167: 243-251.

Noll, F. 1988. L-(+)-Lactate. In: H.U. Bergmeyer (Ed.) Methods of Enzymatic Analysis. VCH Publishers. Cambridge, UK. 1988:582-588.

Philippe, L., Gegout-Pottie, P., Guingamp, C., Bordji, K., Terlain, B., Netter, P., Gillet, P. 1997. Relations between functional, inflammatory, and degenerative parameters during adjuvant arthritis in rats. Am. J. Physiol; 273: R1550-R1556.

Pressley, T.A., Haber, R.S., Loeb, J.N., Edelman, Ismail- Beigi, R. 1986. j.Gen.Physiol.87:591606.

Rodríguez-García, J., Requena, J.R., Rodríguez-Segade, S. 1998. Increased concentrations of serum pentosidine in rheumatoid arthritis. Clin.Chem; 44: 250-255.

Spector, T.D., Perry, L.A., Tubb, G., Huskisson, E.C. 1987. Androgen 
status of females with RA (Letter). Br J Rheumatol; 25: 316-318.

Sutherland, I.W. Structure-function relationships in microbial exopolysaccharides. Biotechnol.

Adv.1994;12: 393-448

Takahashi, M., Kushida, K., Ohishi, T., Kawana, K., Hoshino, H., Uchiyama, A., Inoue, T. 1994. Quantitative analysis of crosslinks pyridinoline and pentosidine in articular cartilage of patients with bone and joint disorders. Arthritis Rheum; 37: 724728.

Testa, I., Rabini, R.A., Corvetta, A., Danieli, G. 1987. Decreased NA+, $\mathrm{K}+$-ATPase activity in erythrocyte membrane from rheumatoid arthritis patients. Scand J Rheumatol; 16: 301305.

Trinder, P. 1969. Determination of glucose in blood using glucose oxidase with an alternative oxygen acceptor. Ann Clin.Biochem; 6: 24-25.

Troughton, P.R., Platt, R., Bird, H., elManzalawi, E., Bassiouni, M., Wright, V. 1996. Synovial fluid interleukin-8 and neutrophil function in rheumatoid arthritis and seronegative polyarthritis. $\mathrm{Br} \mathrm{J}$ Rheumatol; 35:1244-1251.

Vessel, E.S., Osteri, K.C., Bearn, A.G., Kunkel, H.G. 1962. Isozymes of lactic dehydrogenase; their alterations in arthritic synovial fluid and sera. $\mathrm{J}$ Clin Invest; 41: 2012-2019.

Yildirim, K., Senel, K., Karatay, S., Sisecioglu, M., Kiziltunc, A., Ugur, M., Akcay, F. 2005. Serum E-selectin and erythrocyte membrane $\mathrm{Na}+\mathrm{K}+$ ATPase levels in patients with rheumatoid arthritis. Cell Biochem Funct; 23: 285-289. 